TION meetings where he may, after a few successive attendances, acquire confidence enough to rise and express bis views, not leaving the entire field of discussion to selfassured specialists or practical politicians and parliamentarians.

D. L.

\section{Women Medical Missionaries.}

Boston, Mass., Nov. 30, 1395.

To the Editor:-We are desirous of finding a fully qualified medical lady to go to Ceylon as a missionary of the American Board of Commissioners for Foreign Missions at as early a date as possible (not later than Oct., 1896), to open the work of the Woman's Medical Mission in North Ceylon. The new buildings are in process of erection and will be completed according to the contract, furnished throughout and ready for occupancy within a few months. The Medical Mission House for the residence of the lady doctors, is large and commodious. The hospital will accommodate about forty patients. The Nurses' Training Home will accommodate sixteen nurses and a matron. Dr. Louisa H. Grieve (who is acting as a temporary supply until two permanent lady doctors can be secured for this work) has, at the branch dispensary, two days in each week, from fifty to one hundred patients each dispensary day. The branch dispensary will be continued and the new dispensary, which is ten miles distant, will probably receive as many patients. The American Board of Commissioners for Foreign Missions, the oldest and one of the most responsible Missionary Societies in the United States, which, on our recommendation, will appoint the lady doctors and have the general supervision of their work, will provide for the two medical ladies the usual allowances toward outfit, passage and salary, and will provide sufficient funds for the support of a staff of native helpers and for the current expenses of this Medical Mission for Women.

Location. The northern province in Ceylon, in which the Woman's Medical Mission is located, has a population of 300,000 people, all of whom speak the Tamil language. All the women and children would be accessible to the lady doctors.

Misionury Work. Ten missionary families, connected with three societles, are carrying on missionary work. There are about 3,000 native Christians who are communicants, and about 15,000 children under instruction in mission schools.

Medical Mission Work. Rev. Dr. and Mrs. Dr. Scott, both fully qualified doctors and missionaries of the A. B. C. F. M., have the oversight of the Medical Mission for men, which is located about a mile distant from the W. M. M. Last year they treated over 4,000 patients, and they are now enlarging their hospital accommodation. They have expressed their willingness to act as consulting physicians to the W.M.M.

Funds. The value of the land, buildings, furniture, equipment, medicines, instruments, and cash in hand of the $W$. M. M. is over $\$ 20,000$, and the annual income is estimated at about $\$ 3,000$.

Climate. The climate is an even one, the thermometer ranges from 78 degrees to 93 degrees in the shade. The rainfall averages about forty inches in a year. The dry heat is less enervating than the moist heat of many other places in Ceylon and India. Missionaries have lived and labored, in not a few instances, for thirty, forty, and in some cases even fifty years in this Province.

If any fully qualified medical ladies who are readers of your journal, and who have work in the foreign field in view, would write to us, we would gladly give them any further information they might desire regarding this work. Yours truly,

Mary and Margaret W. Leith.

\section{The Oldest but Latest Fad-Hypnotis m .}

To the Editor:-You will agree with me that it is a difficuit matter to make one cause explain all phenomena. Sometime in the past I wrote an article for the Joursal under the heading, "Modern Insanity" and in a jocular way put it as a cause of many unique acts. At that time I had not "read up" on "Hypnotism." Since reading the last number of the JockxAI. I have reason to modify some of my views. Hypnotism in its latest phase assists wonderfully in explaining a phenomena heretofore not understood. For instance. One who is a multiplex personality can say in regard to his unusual acts, that Number 2 or Number 3, did the act, and therefore Number ore is excusable. Whether or not he could make a court or jury believe him is another question. The average juror looks upon himself as a unit and may be hard to convince that any other individual is more. Evidently the "Fool Killer" is dead or has ceased work. How a medical man can be led astray by such idiotic "fads" as spiritualism, hypnotism, clairvoyance and other superstitions is hard to understand; and how a man can believe in hypnotism and yet not believe in "faith cures" is still another mystery. The idea that a man can influence another hundreds of miles away without any means of communication is not mysterious but simply untrue. The believers in hypnotism all agree that a man can not be hypnotized who is not willing. Does this not prove that hypnotism is not a remedy? Can a man by will power alone resist the influence of remedies? Can he keep calomel from purging or ipecac from vomiting by will power? Does it not " make you tired" to think that leading men in the profession will not only listen to this preposterous "fad" but will write it up, and indorse it in the leading medical journal in the United States? I am a little surprised that the editor allowed the "fad" space. When a man loses his identity and becomes two or three or a dozen different men then it is time to quit. When $I$ am in a happier mood I may say more along this line, but for the present am done. Very respectfully submitted,

Uran, Scott Co. Mo.

W. P. Howle, M.D.

\section{The Sun Glass as a Cautery.}

Washington, D. C., Dec. 10, 1895.

To the Editor:-I notice in the last issue of the Journal, a reference to the use of the sun glass as an actual cautery. Permit me to call attention to the fact that this is one of the oldest cauteries. Pliny, writing in the first century, Book xxxvir, chap. 10, (Bohn's edition), says:

"I find it stated by medical men that the very best cautery for the human body is a ball of crystal acted on by the rays of the sun."

It is unfortunate that Pling forbore to give his authority for I can find no other reference to this method of cautery in the ancient writings that I have consulted. Perhaps some of the learned readers of the Journa may inform us. Truly yours, An Otid Member.

\section{Sulfonal in the Vomiting of Pregnancy.}

$$
\text { Allison, Iowa, }
$$

To the Editor:-I have found this medicine a sure relief for this most obstinate trouble. I have been using it over a year, have recommended it to neighboring physicians and never knew it to fail. Those who have tried it say it works like magic. It will relieve hiccough as effectually as well. My method of giving is 10 to 15 grains (60 to 1 ), dissolved in two tablespoonfuls boiling water, and given as hot as the patient can bear it. Sulfonal will stop vomiting of most any character, the quickest, safest and surest of any remedy $n$ the category of medicine. I believe every physician hould know this and hope the Journa $\mathrm{L}$ will pass it around. 